\title{
EVALUASI STANDAR KEMAMPUAN MAHASISWA TERHADAP PEMBELAJARAN METODOLOGI PENELITIAN PADA PROGRAM STUDI D-IV BIDAN PENDIDIK FAKULTAS ILMU KESEHATAN UNIVERSITAS MUHAMMADIYAH TANGERANG
}

\author{
Yayah Huliatunisa \\ Universitas Muhammadiyah Tangerang \\ Email : yhuliatunisa@yahoo.com
}

\begin{abstract}
ABSTRAK
Penelitian ini bertujuan untuk membandingkan kesesuaian standar kemampuan mahasiswa terhadap pembelajaran yang telah dirancang pada mata kuliah Metodologi Penelitian di Program Studi D-IV Bidan Pendidik Fakultas Ilmu Kesehatan Universitas Muhamadiyah Tangerang yang tertuang dalam silabus dan yang diterapkan pada saat proses pembelajaran pada Tahun Akademik 2015/2016.

Penelitian ini dilakukan di Program Studi D-IV Bidan Pendidik Fakultas Ilmu Kesehatan Universitas Muhammadiyah Tangerang, bersifat evaluasi kualitatif dengan Model Evaluasi Goal Free Oriented. Metode pengumpulan data yang digunakan adalah wawancara, observasi dan dokumentasi. Standar Evaluasi yang digunakan adalah Silabus Mata Kuliah Metodologi Penelitian. Pemeriksaan keabsahan data menggunakan teknik triangulasi metode sedangkan teknik analisis data yang digunakan adalah teknik analisis interaktif Miles dan Huberman.

Hasil dari penelitian ini adalah ditemukannya ketidaksesuaian pada kemampuan mahasiswa terhadap pembelajaran Mata Kuliah Metodologi Penelitian di Program Studi DIV Bidan Pendidik Fakultas Ilmu Kesehatan Universitas Muhammadiyah Tangerang Tahun Akademik 2015/2016 dengan standar evaluasi yang telah ditetapkan. Dan menunjukkan bahwa beberapa perbaikan dalam sistem pembelajaran Metodologi Penelitian perlu untuk dilakukan.
\end{abstract}

Kata Kunci: evaluasi, standar kemampuan pembelajaran

\section{PENDAHULUAN}

Pembukaan UUD 1945 menyatakan bahwa salah satu tujuan nasional adalah mencerdaskan kehidupan bangsa. Berbagai upaya dilakukan agar tujuan tersebut dapat tercapai, salah satunya adalah peningkatan mutu pendidikan.

Pendidikan adalah usaha sadar dan terencana untuk mewujudkan suasana belajar dan proses pembelajaran agar peserta didik secara aktif mengembangkan potensi dirinya untuk memiliki kekuatan spiritual keagamaan, pengendalian diri, kepribadian, kecerdasan, akhlak mulia serta keterampilan yang diperlukan dirinya, masyarakat, bangsa dan negara. (UU No 20 tahun 2003, 2003:4).

Salah satu komponen dalam sistem pendidikan adalah pembelajaran.
Pembelajaran itu sendiri merupakan suatu sistem yang didalamnya terdapat berbagai komponen, antara lain tujuan, materi, metode, media, sumber belajar, evaluasi, peserta didik, lingkungan dan guru yang saling berhubungan dan ketergantungan satu sama lain serta berlangsung secara terencana dan sistemik. (Komsiyah, 2012)

Universitas Muhammadiyah Tangerang membuka beberapa Fakultas, antara lain: Fakultas Ekonomi (S.1 Akuntansi, S.1 Manajemen dan D.3 Akuntansi), Fakultas Agama Islam (S.1 PAI, S.1 MPS, S.1 Pendidikan Bahasa Arab), Fakultas Kesehatan (S.1 Keperawatan, D.III Kebidanan dan D.IV Bidan Pendidik), Fakultas Keguruan dan Ilmu Pendidikan (S.1 PGSD, S.1 PG-PAUD, S.1 Pend MTK, S.1 Pend B.Inggris dan S.1 Pend B. 
Indonesia), Fakultas Teknik (S.1 Teknik Informatika, Teknik Elektro, Teknik Mesin dan Teknik Industri), Fakultas Hukum (S.1 Ilmu Hukum) Fakultas Ilmu Sosial dan Ilmu Politik (S.1 Ilmu Pemerintahan dan S.1 Ilmu Komunikasi) dan Program Pascasarjana (Magister Manajemen dan Magister Studi Islam) (http://www.umt.ac.id).

Program Studi D-IV Bidan Pendidik pada Fakultas Ilmu Kesehatan Universitas Muhammadiyah Tangerang mempunyai visi yaitu Menjadi Fakultas Terdepan, Beriman, dan Bertaqwa serta Kompetitif di Bidang Ilmu Keperawatan dan Kebidanan sesuai Perkembangan IPTEK Pada Tahun 2020. Oleh karenanya mata kuliah Metode Penelitian Kebidanan merupakan salah satu fokus capaian dalam usaha pembentukan output lulusan yang sesuai dengan visi tersebut.

Dalam pendidikan kesehatan, khususnya Diploma IV Bidan Pendidik, berdasarkan SK Ka. Badan PPSDMK No. HK. 02.03/I/IV/2/07208.1/2013 visi pendidikan Diploma IV Kebidanan adalah menghasilkan sarjana terapan kebidanan yang kompeten sebagai pemberi asuhan kebidanan (care provider), penggerak masyarakat (community leader), komunikator (communicator), pendidik (educator), pengelola (manager), dan peneliti (researcher). (KEMENKES RI, 2012). Dimana salah satu misi dan tujuannya adalah menghasilkan peneliti yang mampu menyelenggarakan penelitian terapan kebidanan untuk mengembangkan keilmuan. Dengan target capaian pembelajaran yaitu mampu memanfaatkan IPTEKS dalam kegiatan penelitian untuk penyelesaian permasalahan dalam lingkup kebidanan, menguasai konsep teoritis bidang metodologi penelitian, statistik dan metode analisis data secara umum serta konsep teoritis khusus di bidang penelitian terapan kebidanan pada tatanan klinis dan komunitas, mampu memformulasikan penyelesaian masalah penelitian dan mampu mengambil keputusan yang tepat berdasarkan analisis informasi dan data penelitian serta mampu memilih berbagai alternative solusi terhadap permasalahan penelitian serta bertanggung jawab terhadap hasil penelitiannya. (KEMENKES RI, 2012)

Termasuk di dalamnya poin-poin bahan kajian pembelajaran yaitu membaca dan analisis hasil penelitian kebidanan/kesehatan serta laporan penelitian, konsep dasar penelitian, sistematika penelitian, metodologi dalam penelitian, teori probabilitas, sampling dan sample size, uji validitas dan reabilitas, menghitung dan mengolah data dengan menggunakan uji statistic, analisis data dan interpretasi hasil pengolahan data. (KEMENKES RI, 2012)

Dalam sistem pembelajaran terdapat komponen evaluasi. Setiap jenis atau bentuk pendidikan pada waktu-waktu tertentu selama satu periode pendidikan idealnya mengadakan evaluasi terhadap sistem pembelajaran, baik oleh pihak terdidik maupun oleh pendidik, sehingga dapat diketahui proses belajar yang dilakukan cukup efektif memberikan hasil yang baik dan memuaskan atau sebaliknya. (Tayibnapis, 2008)

Evaluasi mempunyai kedudukan yang sangat penting, karena hasil dari kegiatan ini dapat digunakan sebagai input untuk melakukan perbaikan kegiatan pembelajaran. Jika evaluasi menunjukkan kekurangan atau kegagalan, maka sistem pembelajaran baiknya segera mengadakan perbaikan atau perubahan. (Tayibnapis, 2008)

Berdasarkan studi pendahuluan yang telah dilakukan pada Program Studi D-IV Bidan Pendidik Fakultas Ilmu Kesehatan Universitas Muhammadiyah Tangerang, didapatkan gambaran awal mengenai pembelajaran Metodologi Penelitian Kebidanan di mana beberapa mahasiswa mengatakan bahwa mereka kesulitan dalam mengikuti proses pembelajaran dan mengerjakan proposal skripsi, meskipun pada hasil UTS didapati bahwa nilai ratarata mahasiswa cukup memuaskan. 
Hal ini akan mengakibatkan tidak bertemunya dua titik, antara rancangan pembelajaran dengan hasil yang diperoleh dari proses pembelajaran, sehingga menyebabkan ketidakseimbangan antara tuntutan kompetensi seorang lulusan D-IV Bidan Pendidik dengan kemampuan yang sesungguhnya dimiliki. Dalam kehidupan mendatang, hal ini akan berdampak timbulnya hambatan-hambatan dalam pelaksanaan tugas dikemudian hari.

Berdasarkan hal tersebut di atas, maka penelitian ini bertujuan untuk membandingkan kesesuaian standar kemampuan mahasiswa terhadap pembelajaran yang telah dirancang pada mata kuliah Metodologi Penelitian di Program Studi D-IV Bidan Pendidik Fakultas Ilmu Kesehatan Universitas Muhamadiyah Tangerang yang tertuang dalam silabus dan yang diterapkan pada saat proses pembelajaran pada Tahun Akademik 2015/2016, dalam rangka meningkatkan capaian hasil belajar beserta kemampuan pengaplikasian Metodologi Penelitian Kebidanan semaksimal mungkin dari peserta didik di tahun yang akan datang.

\section{EVALUASI}

Menurut Arikunto (2008), bahwa Evaluasi adalah kegiatan untuk mengumpulkan informasi tentang bekerjanya sesuatu, yang selanjutnya informasi tersebut digunakan untuk menentukan alternatif yang tepat dalam mengambil sebuah keputusan.

Soeharto (2003:64) mengemukakan bahwa, "evaluasi sistem pembelajaran berarti evaluasi terhadap kombinasi dari berbagai komponen yang menerapkan suatu pola manajemen tertentu yang sengaja dirancang, dipilih, dan dilaksanakan agar timbul peristiwa belajar yang bertujuan dan terkontrol".

Dari rumusan tentang evaluasi ini, dapat diperoleh gambaran bahwa evaluasi adalah suatu proses yang sistematis dan berkelanjutan untuk menentukan kualitas (nilai dan arti) daripada sesuatu, berdasarkan pertimbangan dan kriteria tertentu untuk membuat suatu keputusan.

Dalam evaluasi terdapat beberapa model yang dikenal, menurut Tayibnapis (2011) model evaluasi adalah sebagai berikut :

a. Goal Oriented Evaluation / Model Tyler

Dalam model ini, yang menjadi objek pengamatan adalah tujuan dari program yang sudah di tetapkan jauh sebelum program di mulai. Evaluasi ini di lakukan secara berkesinambungan untuk mengetahui sejauh mana tujuan tersebut sudah terlaksana di dalam proses pelaksanaannya. Model ini menggunakan tujuan program sebagai kriteria untuk menentukan keberhasilan dari program. (Tayibnapis, 2011)

b. Goal Free Evaluation Model ( Michael Scriven )

1) Pengertian

Goal Free Evaluation Model adalah model evaluasi yang dikembangkan oleh Scriven. Dalam Goal Free Evaluation, Scriven mengemukakan bahwa dalam melaksanakan evaluasi program evaluator tidak perlu memperhatikan apa yang menjadi tujuan program. Yang perlu diperhatikan dalam program tersebut adalah bagaimana kerjanya (kinerja) suatu program, dengan jalan mengidentifikasi penampilanpenampilan yang terjadi (pengaruh) baik hal-hal yang positif (yaitu hal yang diharapkan) maupun hal-hal yang negatif (yang tidak diharapkan). (Tayibnapis, 2011)

Evaluasi model goal free evaluation, fokus pada adanya perubahan perilaku yang terjadi sebagai dampak dari program yang diimplementasikan, melihat dampak sampingan baik yang diharapkan maupun yang tidak diharapkan, dan membandingkan dengan sebelum program dilakukan. Evaluasi juga 
membandingkan antara hasil yang dicapai dengan besarnya biaya yang dikeluarkan untuk program tersebut atau melakukan cost benefit analysis. (Tayibnapis, 2011)

Menurut Scriven, dalam pelaksanaan evaluasi program, Evaluator tidak perlu memperhatikan apa yang menjadi tujuan program, akan tetapi bagaimana bekerjanya suatu program, dengan cara mengidentifikasi penampilanpenampilan yang terjadi, baik halhal positif maupun yang negatif. Alasannya karena ada kemungkinan evaluator terlalu rinci mengamati tiap-tiap tujuan khusus. Jika tujuantujuan khusus tercapai artinya terpenuhi dalam penampilan. (Mirza, 2013)

Dalam model ini, evaluator sengaja menghindar untuk mengetahui tujuan program, berfokus pada hasil yang sebenarnya bukan hasil yang di rencanakan, hubungan evaluator dan peserta di buat seminimal mungkin, dan tujuan yang telah di rumuskan terlebih dahulu tidak dibenarkan untuk menyempitkan fokus evaluasi. (Tayibnapis, 2011)

Tujuan program tidak perlu diperhatikan karena kemungkinan evaluator terlalu rinci mengamati tiap-tiap tujuan khusus. Jika masing-masing tujuan khusus tercapai, artinya terpenuhi dalam penampilan tetapi evaluator lupa memperhatikan sejauh mana masing-masing penampilan tersebut mendukung penampilan terakhir yang diharapkan oleh tujuan umum maka akibatnya jumlah penampilan khusus ini tidak banyak bermanfaat. Dapat disimpulkan bahwa, dalam model ini bukan berarti lepas dari tujuan tetapi hanya lepas dari tujuan khusus. Model ini hanya mempertimbangkan tujuan umum yang akan dicapai oleh program, bukan secara rinci perkomponen yang ada. (Mirza, 2013)

Scriven menekankan bahwa evaluasi itu adalah interpretasi Judgement ataupun explanation dan evaluator yang merupakan pengambil keputusan dan sekaligus penyedia informasi. (Mirza, 2013)

2) Ciri - Ciri Evaluasi Bebas Tujuan yaitu :

- Evaluator sengaja menghindar untuk mengetahui tujuan program

- Tujuan yang telah dirumuskan terlebih dahulu tidak dibenarkan menyempitkan fokus evaluasi

- Evaluasi bebas tujuan berfokus pada hasil yang sebenarnya, bukan pada hasil yang direncanakan

- Hubungan evaluator dan manajer atau dengan karyawan proyek dibuat seminimal mungkin

- Evaluasi menambah kemungkinan ditemukannya dampak yang tidak diramalkan

3) Fokus Evaluasi Goal Free Evaluation

Model Goal-Free Evaluation berfokus pada hasil yang sebenarnya dari suatu program atau kegiatan, bukan hanya tujuan-tujuan yang teridentifikasi. Jenis model memungkinkan teknolog untuk mengidentifikasi dan mencatat hasil yang tidak mungkin telah diidentifikasi oleh perancang program (Guskey, 2000).

Model ini berfokus pada hasil tanpa goal, model lain berfokus pada proses pengambilan keputusan dan menyediakan administrator kunci dengan analisis mendalam untuk membuat keputusan yang adil 
dan tidak bias. (Tayibnapis, 2011)

4) Kekurangan dan Kelebihan Goal Free Evaluation

Model evaluasi Goal Free Evaluation ini mempunyai kekurangan dan kelebihannya. Kelebihan dari model bebas tujuan di antaranya adalah:

- Evaluator tidak perlu memperhatikan secara rinci setiap komponen, tetapi hanya menekankan pada bagaimana mengurangi prasangka (bias).

- Model ini menganggap pengguna sebagai audiens utama. Melalui model ini, scriven ingin evaluator mengukur kesan yang didapat dari sesuatu program dibandingkan dengan kebutuhan pengguna dan tidak membandingkannya dengan pihak penganjur.

- Pengaruh konsep pada masyarakat, bahwa tanpa mengetahui tujuan dari kegiatan yang telah dilakukan, seorang penilai bisa melakukan evaluasi.

- Kelebihan lain, dengan munculnya model bebas tujuan yang diajukan oleh Scriven, adalah mendorong pertimbangan setiap kemungkinan pengaruh tidak saja yang direncanakan, tetapi juga dapat diperhatikan sampingan lain yang muncul dari produk.

Walaupun demikian, yang diajukan Scriven ternyata juga memiliki kelemahan seperti berikut :

- Model bebas tujuan ini pada umumnya bebas menjawab pertanyaan penting, seperti apa pengaruh yang telah diperhitungkan dalam suatu peristiwa dan bagaimana mengidentifikasi pengaruh tersebut.

- Walaupun ide Scriven bebas tujuan bagus untuk membantu kegiatan yang paralel dengan evaluasi atas dasar kejujuran, pada tingkatan praktis Scriven tidak terlalu berhasil dalam menggambarkan bagaimana evaluasi sebaiknya benarbenar dilaksanakan.

- Tidak merekomendasikan bagaimana menghasilkan penilaian kebutuhan walau pada akhirnya mengarah pada penilaian kebutuhan.

- Diperlukan evaluator yang benar-benar kompeten untuk dapat melaksanakan evaluasi model ini.

- Langkah-langkah sistematis yang harus dilakukan dalam evaluasi hanya menekankan pada objek sasaran saja.

Model bebas tujuan merupakan titik evaluasi program, dimana objek yang dievaluasi tidak perlu terkait dengan tujuan dari objek atau subjek tersebut, tetapi langsung kepada implikasi keberadaan program apakah bermanfaat atau tidak objek tersebut atas dasar penilaian kebutuhan yang ada. (Tayibnapis, 2013)

a. CIPP Model ( Context, Input, Process, Product )

Konsep evaluasi model CIPP pertama kali di tawarkan oleh stufflebeam pada tahun 1965 sebagai hasil dari usahanya dalam mengevaluasi ESEA (The Elementary and Secondary Education Act). Stufflebeam menawarkan konsep tersebut dengan pandangan bahwa tujuan penting dari sebuah evaluasi adalah bukan untuk membuktikan sesuatu, akan tetapi adalah untuk memperbaikinya. Evaluasi 
model CIPP dapat di terapkan dalam bidang pendidikan, manajemen, perusahaan dan sebagainya, serta dalam berbagai jenjang, baik proyek, program maupun institusi.

5) Model Empat Level Donald L. Kirkpatrick

Merupakan model evaluasi pelatihan yang di kembangkan pertama kali oleh Kirkpatrick (1959) dengan menggunakan empat level dalam mengkategorikan hasil-hasil pelatihan.

4 (Empat) level tersebut dapat di rinci sebagai berikut :

- Evaluasi Reaksi ( Evaluating Reaction )

Reaksi dilakukan untuk mengukur tingkat reaksi yang di desain agar mengetahui opini para peserta pelatihan mengenai program pelatihan

- Evaluasi Pembelajaran Evaluating Learning )

Ada tiga hal yang dapat Instruktur ajarkan dalam program training, yaitu pengetahuan, sikap dan keterampilan.

- Evaluasi Tingkah Laku ( Evaluating Behavior )

Penilaian tingkah laku di fokuskan pada perubahan tingkah laku setelah peserta kembali ke tempat kerja.

- Evaluasi Hasil / Dampak Program Pelatihan

Evaluating Result )

Evaluasi hasil di fokuskan pada hasil akhir ( Final Result ) yang terjadi karena peserta telah mengikuti suatu program.

6) Model UCLA

Evaluasi model ini dikembangkan oleh Alkin pada tahun $1969 . \quad$ Alkin mendefinisikan evaluasi sebagai suatu proses meyakinkan keputusan, memilih informasi yang tepat, mengumpulkan dan menganalisis informasi.

Lima macam evaluasi yang dikemukakan Alvin :

- System assesment, yang memberikan informasi tentang keadaan atau posisi sistem.

- Program Planning, membantu pemilihan program tertentu yang mungkin akan berhasil memenuhi kebutuhan program.

- Program implementation, yang menyiapkan informasi apakah program sudah di perkenalkan kepada kelompok tertentu.

- Program Improvement, yang memberikan informasi tentang bagaimana program berfungsi dan bagaimana program berjalan.

- Program certification, yang memberikan informasi tentang informasi atau guna program.

7) Model Formatif vs Sumatif Model ini di kembangkan oleh Scriven pada tahun1967. Menurut Scriven evaluasi terhadap program dapat di bedakan menjadi dua :

- Evaluasi Formatif

Adalah proses menyediakan dan menggunakan informasi untuk di jadikan dasar pengambilan keputusan dalam rangka meningkatkan kualitas produk atau program instruksional.

- Evaluasi Sumatif

Evaluasi yang dilaksanakan saat program telah selesai dan bagi kepentingan pihak luar atau para pengambilan keputusan. 
8) Model Kesesuaian

Menurut model ini, evaluasi adalah suatu kegiatan untuk melihat (congruence) antara tujuan dengan hasil belajar yang telah di capai.

9) Model Pengukuran

Pengukuran di gunakan untuk menentukan kuantitas suatu sifat (attribute) tertentu yang dimiliki oleh objek, orang maupun peristiwa dalam bentuk unit ukuran tertentu.

10) Model Yang Berorientasi Pada Tujuan

Model evaluasi ini menggunakan tujuan pembelajaran umum (TPU) dan tujuan pembelajaran khusus (TPK) sebagai kriteria untuk menentukan keberhasilan. Tujuan model ini membantu pendidik merumuskan tujuan dan menjelaskan hubungan antar tujuan dengan kegiatan.

Said Hamid Hasan (1988 : 83

- 136) mengelompokkan model evaluasi sebagai berikut :
- Model evaluasi kuantitatif : model Tyler, model teoritik, Tyler and Maguire, model pendekatan sistem Alkin, model countinence stake, model CIPP, model ekonomi makro.

- Model evaluasi Kualitatif : model Studi Kasus, model Iluminatif, dan model Responsive.

Fungsi utama evaluasi dalam hal ini adalah menyediakan informasi-informasi yang berguna bagi pihak decision maker untuk menentukan kebijakan yang akan diambil berdasarkan evaluasi yang telah dilakukan. Dan dalam prosesnya di butuhkan alat pengumpulan data evaluasi. Selanjutnya data yang terkandung dalam dokumen dapat digali, dicacah, dikumpulkan dengan menggunakan daftar ceklis atau pedoman dokumentasi.

Tabel di bawah ini meringkas masingmasing alat pengumpulan data selama pelaksanaan evaluasi, menurut Arikunto (2010) :

Tabel. 1

Alat Pengumpulan Data Evaluasi

\begin{tabular}{|c|c|c|c|}
\hline Alat & Kapan Dilakuan & Keuntungan & Kelemahan \\
\hline $\begin{array}{l}\text { Tes, } \\
\text { kuisioner, } \\
\text { survei, } \\
\text { atau daftar } \\
\text { ceklis. }\end{array}$ & $\begin{array}{l}\text { Dilakukan ketika } \\
\text { membutuhkan } \\
\text { data yang } \\
\text { banyak secara } \\
\text { cepat dan mudah } \\
\text { dari orang-orang } \\
\text { tanpa merasa } \\
\text { terancam/tidak } \\
\text { nyaman. }\end{array}$ & 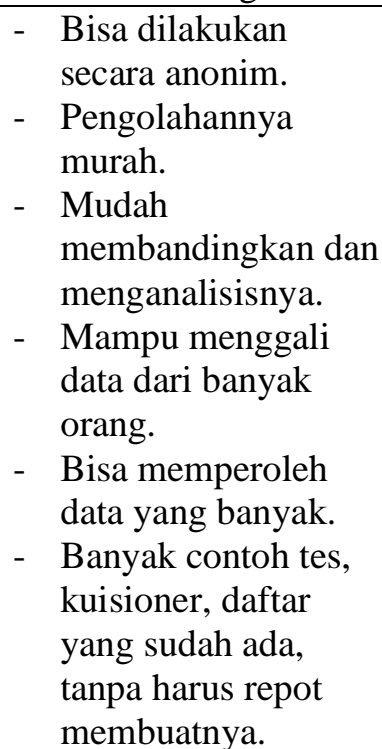 & $\begin{array}{ll}\text { - } & \text { Bisa mendapatkan } \\
& \text { feedback yang tidak } \\
\text { seksama. } \\
\text { - } \\
\text { Respons (tanggapan) } \\
\text { bisa menyimpang. } \\
\text { - } \\
\text { - } \\
\text { Impersonal. } \\
\text { keahliam survei, perlu sampling. } \\
\text { - } \\
\text { Tidak akan } \\
\text { mendapatkan cerita } \\
\text { sepenuhnya. }\end{array}$ \\
\hline wawancara & $\begin{array}{l}\text { Ketika } \\
\text { menghendaki }\end{array}$ & $\begin{array}{ll}\text { - } & \text { Mendapatkan } \\
& \text { informasi yang }\end{array}$ & $\begin{array}{l}\text { - Memakan banyak } \\
\text { waktu. }\end{array}$ \\
\hline
\end{tabular}




\begin{tabular}{|c|c|c|c|}
\hline & $\begin{array}{l}\text { pemahaman, } \\
\text { kesan, atau } \\
\text { pengalaman, } \\
\text { seseorang atau } \\
\text { unit } \\
\text { kerja/organisasi, } \\
\text { atau juga untuk } \\
\text { mempelajari } \\
\text { secara lebih jauh } \\
\text { jawaban } \\
\text { tes/kuesioner } \\
\text { mereka. }\end{array}$ & $\begin{array}{l}\text { penuh dan } \\
\text { mendalam. } \\
\text { - } \text { Membangun } \\
\text { hubungan dengan } \\
\text { responden/informan. } \\
\text { - }\end{array}$ & $\begin{array}{ll}\text { - } & \text { Bisa sulit melakukan } \\
\text { analisis dan } \\
\text { perbandingan. } \\
\text { - } & \text { Bisa membutuhkan } \\
\text { dana yang banyak. } \\
\text { - } & \text { Pewawancara bisa } \\
\text { membiaskan } \\
\text { tanggapan mereka. }\end{array}$ \\
\hline $\begin{array}{l}\text { Analisis } \\
\text { dokumen } \\
\text { dan artifak }\end{array}$ & $\begin{array}{l}\text { Ketika } \\
\text { menghendaki } \\
\text { kesan } \\
\text { bagaimanaa } \\
\text { program berjalan } \\
\text { tanpa } \\
\text { mengganggu } \\
\text { program atau } \\
\text { orang-orang } \\
\text { yang terlibat } \\
\text { dalam } \\
\text { pelaksanaan } \\
\text { program. }\end{array}$ & $\begin{array}{ll}\text { - } & \text { Mendapatkan data } \\
\text { yang komprehensif } \\
\text { dan sifatnya historis. } \\
\text { - } & \text { Tidak menghentikan } \\
\text { rutinitas orang-orang } \\
\text { dalam melaksanakan } \\
\text { aktivitasnya. } \\
\text { - } \\
\text { Data akan senantiasa } \\
\text { siap digali. } \\
\text { - } & \text { Kadang bisa bias }\end{array}$ & $\begin{array}{ll}\text { - } & \text { Kadang memakan } \\
\text { banyak waktu. } \\
\text { - } \\
\text { Data mungkin saja } \\
\text { tidak lengkap. } \\
\text { - } \text { Harus jelas apa yang } \\
\text { akan dicari. } \\
\text { - } \\
\text { Bukan alat yang } \\
\text { fleksibel untuk } \\
\text { menggali data, hanya } \\
\text { terbatas apa yang } \\
\text { terdapat } \\
\text { - } \\
\text { pada dokumen atau } \\
\text { artifak itu }\end{array}$ \\
\hline Observasi & $\begin{array}{l}\text { Untuk } \\
\text { mendapatkan } \\
\text { data yang akurat } \\
\text { tentang } \\
\text { bagaimana } \\
\text { program } \\
\text { sebenarnya } \\
\text { berjalan, } \\
\text { khususnya } \\
\text { mengenai } \\
\text { proses. }\end{array}$ & $\begin{array}{ll}\text { - } & \text { Memandang } \\
\text { pelaksanaan program } \\
\text { sebagaimana adanya. } \\
\text { - } \\
\text { Bisa beradaptasi } \\
\text { dengan kejadian } \\
\text { yang sedang } \\
\text { berlangsung. }\end{array}$ & 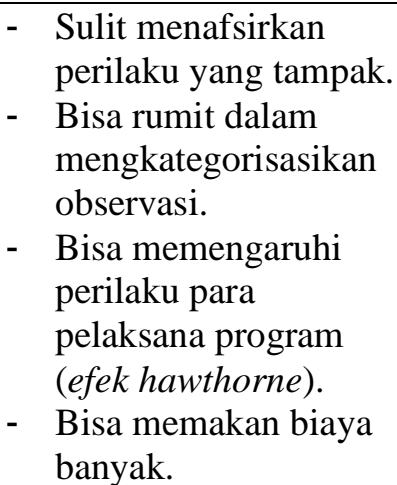 \\
\hline $\begin{array}{l}\text { Kelompok } \\
\text { fokus }\end{array}$ & $\begin{array}{l}\text { Menggali suatu } \\
\text { topik secara } \\
\text { mendalam } \\
\text { melalui diskusi } \\
\text { kelompok. } \\
\text { Misalnya reaksi } \\
\text { atas pengalaman } \\
\text { atau saran pada } \\
\text { program, atau } \\
\text { memahami } \\
\text { keluhan. }\end{array}$ & $\begin{array}{ll}\text { - } & \text { Alat cepat dan } \\
\text { terpercaya untuk } \\
\text { mendapatkan kesan. } \\
\text { - } & \text { Aalt yang paling } \\
\text { efisien dalam } \\
\text { mendapatkan data } \\
\text { dengan waktu } \\
\text { singkat. } \\
\text { - Dapat menangkap } \\
\text { inti program. }\end{array}$ & $\begin{array}{ll}\text { - } & \text { Bisa sulit } \\
\text { menganalisis respons. } \\
\text { - } & \text { Perlu fasilitator yang } \\
\text { bagus demi keamanan } \\
\text { dan kedekatan. } \\
\text { - } & \text { Sulit menjadwal } \\
\text { waktu. }\end{array}$ \\
\hline
\end{tabular}

STANDAR KEMAMPUAN DALAM PEMBELAJARAN

Menurut Kamus Besar Bahasa Indonesia, standar berarti ukuran tertentu yang dipakai sebagai patokan. Sedangkan standar dalam kaitannya dengan kemampuan dalam pembelajaran adalah merupakan kemampuan, keterampilan dan sikap peserta didik dalam kaitannya dengan ketercapaian hasil pembelajaran dan juga 
penguasaan terhadap suatu pokok bahasan atau mata ajar tertentu.

Santoso (2015) mengungkapkan, kata dasar "pembelajaran" adalah belajar. Dalam arti sempit pembelajaran dapat diartikan sebagai suatu proses atau cara yang dilakukan agar seseorang dapat melakukan kegiatan belajar, sedangkan belajar adalah suatu proses perubahan tingkah laku karena interaksi individu dengan lingkungan dan pengalaman. Dengan kata lain, pembelajaran adalah proses untuk membantu peserta didik agar dapat belajar dengan baik. (Komsiyah, 2012)

Belajar merupakan suatu proses perubahan perilaku yang muncul karena pengalaman, sedangkan pembelajaran merupakan suatu sistem yang bertujuan untuk membantu proses belajar tersebut, yang berisi serangkaian peristiwa yang sebelumnya telah dirancang, disusun sedemikian rupa untuk mempengaruhi dan mendukung terjadinya proses belajar.

Dalam proses belajar, kurikulum mempunyai peranan sangat penting, yang mana dengan kurikulum, proses belajar diarahkan pada proses pengembangan, pembudayaan dan pemberdayaan peserta didik yang berlangsung sepanjang hayat. Kurikulum juga mencerminkan keterkaitan antara unsur-unsur pendidikan formal, nonformal, dan informal, dengan memperhatikan kondisi dan tuntutan lingkungan yang selalu berkembang serta arah pengembangan manusia seutuhnya

Dalam dunia pendidikan, kurikulum berfungsi sebagai alat untuk mencapai tujuan-tujuan yang diinginkan serta mengatur segala kegiatan yang berlangsung. Kurikulum tercipta dari pemikiran para tokoh sehingga ada masanya kurikulum akan mengalami perkembangan seiring dengan pemikiran para tokoh dan kebutuhan yang mendasarinya. Pengembangan kurikulum tidak dapat lepas dari berbagai aspek yang mempengaruhinya, seperti cara berpikir, system nilai, proses pengembangan, kebutuhan peserta didik, kebutuhan masyarakat maupun arah program pendidikan itu sendiri.

Karena pengajaran merupakan suatu system, itu mengindikasikan artinya keseluruhan yang terdiri dari komponenkomponen yang berinteraksi antara satu dengan yang lainnya untuk mencapai tujuan pengajaran yang telah ditetapkan sebelumnya. Komponen-komponen tersebut merupakan bagian dari suatu sistem yang memiliki peran secara keseluruhan berlangsungnya suatu proses untuk mencapai tujuan sistem. Jadi, komponen pendidikan adalah bagianbagian dari sistem proses pendidikan yang menentukan berhasil atau tidaknya proses pendidikan tersebut.

Komponen-komponen dalam sistem pembelajaran tersebut menurut Santoso (2011), yaitu:
a. Tujuan
b. Isi/materi pelajaran
c. Strategi /metode
d. Alat dan sumber
e. Evaluasi

Semua komponen dalam sistem pengajaran saling berhubungan dan saling mempengaruhi untuk mencapai tujuan pengajaran, karena proses pengajaran dapat terselenggara secara lancar, efisien, dan efektif jika adanya interaksi yang positif, konstruktif, dan produktif antara berbagai komponen yang terkandung di dalam sistem pengajaran tersebut.

Dari berbagai uraian pada poin-poin sebelumnya peneliti menyimpulkan bahwa evaluasi dalam kemampuan pembelajaran berarti suatu proses atau kegiatan yang sistematis, berkelanjutan, dan menyeluruh dalam rangka pengendalian, penjaminan dan penetapan kualitas penerimaan pembelajaran terhadap berbagai komponen sistem pembelajaran, berdasarkan pertimbangan dan kriteria tertentu sebagai bentuk pertanggungjawaban pendidik terhadap peserta didik dalam melaksanakan proses pembelajaran.

Karena belajar adalah suatu proses yang menimbulkan terjadinya suatu perubahan atau pembaharuan dalam tingkah laku atau 
kecakapan, maka sampai dimanakah perubahan itu dapat tercapai atau berhasil baik atau tidaknya belajar itu tergantung kepada bermacam-macam factor. Faktor yang mempengaruhi seseorang dalam belajar secara umum dibagi menjadi dua bagian yaitu faktor intern yang berasal dari dalam dan faktor ekstern atau berasal dari luar. Antar kedua faktor itu masing masing bisa mempengaruhi seseorang untuk meningkatkan prestasinya yang diperoleh dengan cara belajar. (Dimyati, 2011).

Berikut faktor-Faktor

yang mempengaruhi Pembelajaran menurut Prayitno,(2009):

a. Faktor intern

Faktor intern adalah faktor yang ada dalam diri individu yang sedang belajar. Faktor intern ini dapat dibagi menjadi 3 (tiga) faktor yaitu faktor jasmaniah, faktor psikologi, dan faktor kelelahan.

1) Faktor jasmaniah

Faktor jasmaniah terbagi menjadi dua, yaitu faktor kesehatan dan cacat tubuh. Proses belajar seseorang akan terganggu jika kesehatan seseorang terganggu. Sedangkan cacat tubuh adalah sesuatu yang menyebabkan kurang baik atau kurang sempurna mengenai tubuh, misal buta, tuli, dan lain-lain.

2) Faktor psikologis

Sekurang-kurangnya ada 7 (tujuh) faktor yang tergolong kedalam faktor psikologis yang mempengaruhi prestasi belajar, faktor-faktor tersebut adalah :

- Inteligensi

Inteligensi adalah kecakapan yang terdiri dari 3 (tiga) jenis yaitu kecakapan untuk menghadapi dan menyesuaikan kedalam situasi yang baru dengan cepat dan efektif, mengetahui atau menggunakan konsep-konsep yang abstrak secara efektif, mengetahui relasi, dan mempelajarinya dengan cepat. Inteligensi besar pengaruhnya terhadap kemajuan belajar. Dalam situasi yang sama, peserta didik yang mempunyai tingkat inteligensi yang tinggi akan lebih berhasil daripada yang mempunyai tingkat inteligensi yang rendah.

- Perhatian

Seorang peserta didik harus mempunyai perhatian terhadap bahan yang dipelajarinya, jika bahan pelajaran tidak menjadi perhatian peserta didik, maka timbul kebosanan, sehingga peserta didik tidak lagi suka belajar. Maka dari itu diusahakan bahan pelajaran selalu menarik perhatian dengan cara menyesuaikan pelajaran itu sesuai dengan hobi atau bakat peserta didik.

- Minat

Minat adalah kecenderungan yang tetap untuk memperhatikan dan mengenang beberapa kegiatan. Kegiatan yang diminati seseorang, diperhatikan terus menerus yang disertai dengan rasa, begitu pula sebaliknya. Berbeda dengan perhatian, minat selalu diikuti dengan perasaan senang dan dari situ diperoleh kepuasan.

- Bakat

Bakat adalah kemampuan untuk belajar. Kemampuan itu baru akan terrealisasi menjadi kecakapan yang nyata sesudah belajar atau berlatih.

- Motif

Motif erat hubungannya dengan tujuan yang akan dicapai. Dalam proses belajar haruslah diperhatikan apa yang dapat mendorong peserta didik agar dapat belajar dengan baik atau padanya mempunyai motif untuk berpikir dan memusatkan perhatian, merencanakan, dan melaksanakan kegiatan yang 
berhubungan atau menunjang belajar.

Motif yang kuat sangatlah perlu didalam belajar, didalam membentuk motif yang kuat itu dapat dilaksanakan dengan adanya latihan-latihan atau kebiasaan-kebiasaan dan pengaruh lingkungan yang memperkuat.

- Kematangan

Kematangan adalah suatu tingkat atau fase dalam pertumbuhan seseorang dimana alat-alat tubuhnya sudah siap untuk melaksanakan kecakapan baru. Kematangan belum berarti anak dapat melaksanakan kegiatan secara terus menerus untuk itu diperlukan latihan-latihan dan pelajaran. Dengan kata lain anak yang sudah siap (matang) belum dapat melaksanakan kecakapannya sebelum belajar. Belajar akan lebih berhasil jika anak sudah siap (matang).

- Kesiapan

Kesiapan adalah kesediaan untuk memberi respon atau bereaksi. Kesiapan itu timbul dari dalam diri seseorang dan juga berhubungan dengan kematangan, karena kematangan berarti kesiapan untuk melaksanakan kecakapan. Kesiapan ini perlu diperhatikan dalam proses belajar, karena jika peserta didik belajar dan peserta didik sudah ada kesiapan, maka hasil belajar akan lebih baik.

3) Faktor kelelahan

Kelelahan dibedakan menjadi 2 (dua) macam yaitu kelelahan jasmani dan kelelahan rohani. Kelelahan jasmani dapat disebabkan oleh aktivitas peserta didik yang terlalu banyak, sehingga menyebabkan peserta didik jatuh sakit. Sedangkan kelelahan rohani, dapat terjadi pada peserta didik, karena peserta didik mengalami berbagai masalah sehingga menjadi beban pikirannya.

\section{b. Faktor ekstern}

Faktor ekstern adalah faktor yang ada diluar diri individu yang sedang belajar. Faktor ekstern yang berpengaruh terhadap prestasi belajar dapat dikelompokkan menjadi 3 (tiga) faktor, yaitu: faktor keluarga, sekolah, dan faktor masyarakat.

1) Faktor keluarga

Berupa cara orang tua mendidik, relasi antar anggota keluarga, suasana rumah tangga, keadaan ekonomi keluarga, pengertian orang tua dan latar belakang budaya. Pola asuh orang tua yang terbaik dalam mengasuh anak adalah dengan penuh bijaksana. Orang tua yang bijaksana adalah orang tua yang tahu mempergunakan situasi dan kondisi untuk mendidik anak.

Orang tua harus mampu menciptakan hubungan yang harmonis yang memberikan keamanan dan kebebasan psikologis anak untuk berprestasi. Di dalam menumbuhkan motivasi belajar anak sehingga dapat menunjang prestasi belajar di sekolah, orang tua harus mampu menanamkan kepercayaan diri kepada anak bahwa mampu berprestasi dan selanjutnya orang tua harus menghargai apapun prestasi yang dicapai anak.

2) Faktor sekolah

Faktor sekolah yang mempengaruhi belajar ini mencakup metode mengajar, kurikulum, relasi guru dengan peserta didik, relasi peserta didik dengan peserta didik, disiplin sekolah, alat pengajaran, waktu sekolah, standar pelajaran di atas ukuran, keadaan gedung, metode belajar, dan tugas rumah.

Metode mengajar adalah suatu cara atau jalan yang harus dilalui didalam mengajar. Metode mengajar guru yang kurang baik akan mempengaruhi belajar peserta didik 
yang tidak baik pula. Metode mengajar yang kurang baik itu dapat terjadi misal karena guru kurang persiapan dan kurang menguasai bahan pelajaran, sehingga guru tersebut menyampaikannya tidak jelas. Selain itu juga sikap guru terhadap peserta didik dan terhadap mata pelajaran itu sendiri tidak baik, sehingga peserta didik kurang senang terhadap pelajaran ataupun gurunya, dan akibatnya peserta didik malas untuk belajar. Agar peserta didik dapat belajar dengan baik, maka metode mengajar harus diusahakan dengan tepat, efisien, dan se-efektif mungkin.

Kurikulum diartikan sebagai sejumlah kegiatan yang diberikan kepada peserta didik. Kegiatan itu sebagian besar adalah menyajikan bahan pelajaran agar peserta didik menerima, meguasai dan mengembangkan bahan pelajaran itu. Kurikulum yang kurang baik berpengaruh tidak baik terhadap belajar peserta didik. Kurikulum yang tidak baik misal kurikulum yang terlalu padat, diatas kemampuan peserta didik, tidak sesuai dengan bakat, minat, dan perhatian peserta didik.

Kedisiplinan sekolah erat hubungannya dengan kerajinan peserta didik dalam sekolah dan juga dalam belajar. Seluruh staf sekolah yang mengikuti tata tertib dan bekerja dengan disiplin membuat peserta didik menjadi disiplin pula, selain itu juga memberi pengaruh yang positif terhadap belajarnya. Dengan demikian agar peserta didik belajar lebih maju, peserta didik harus disiplin didalam belajar baik disekolah, dirumah, dan diperpustakaan dan kondisi tersebut harus didukung dengan disiplin dari guru beserta staf yang lainnya.

Waktu sekolah adalah waktu terjadinya proses belajar mengajar disekolah, waktu itu dapat pagi, siang, sore atau malam hari dan sangat berpengaruh di dalam belajar. Jika terjadi peserta didik dipaksa masuk sekolah di sore hari, sebenarnya kurang dapat dipertanggungjawabkan karena peserta didik harus beristirahat, tetapi terpaksa masuk sekolah, sehingga mereka mendengarkan pelajaran sambil mengantuk, sukar berkonsentrasi dan sebagainya. Jadi memilih waktu sekolah yang tepat akan memberi pengaruh positif terhadap belajar.

Metode belajar peserta didik adalah faktor ekstern dalam keberhasilan belajar peserta didik. Banyak peserta didik melaksanakan cara belajar yang tidak efektif. Dalam hal ini perlu pembinaan dari guru. Dengan cara belajar yang efektif akan meningkatkan prestasi belajar peserta didik, dan juga dalam pembagian waktu untuk belajar. Kadang-kadang peserta didik belajar dengan tidak teratur atau terus menerus, karena besok akan tes. Dengan belajar demikian peserta didik akan kurang beristirahat, bahkan mungkin dapat jatuh sakit. Maka perlu belajar secara teratur setiap hari, dengan pembagian waktu yang baik, memilih cara belajar yang tepat dan cukup istirahat akan meningkatkan hasil belajar.

3) Faktor masyarakat

Masyarakat merupakan faktor ekstern yang juga berpengaruh terhadap belajar peserta didik. Pengaruh itu terjadi karena keberadaanya peserta didik dalam masyarakat, mass media, teman bergaul, dan bentuk kehidupan masyarakat. Kegiatan peserta didik dalam masyarakat dapat menguntungkan terhadap perkembangan pribadinya. Tetapi jika peserta didik ambil bagian dalam kegiatan masyarakat yang terlalu banyak, misal berorganisasi, 
belajarnya akan terganggu, lebihlebih jika tidak bijaksana dalam mengatur waktu. Perlulah kiranya membatasi kegiatan peserta didik dalam masyarakat supaya jangan sampai mengganggu belajarnya. Jika mungkin memilih kegiatan yang mendukung belajar. Kegiatan itu misalnya kursus atau bimbingan belajar, kelompok diskusi, dan lain sebagainya.

\section{METODOLOGI EVALUASI}

Penelitian ini bersifat kualitatif evaluative yang menekankan arti dari suatu pengalaman untuk sejumlah individu, dengan tujuan untuk membandingkan, menghasilkan atau menemukan suatu teori yang berhubungan dengan situasi tertentu, dengan cara menggali pengalaman mahasiswa saat menjalani proses pembelajaran mata kuliah Metodologi Penelitian di Program Studi D-IV Bidan Pendidik Fakultas Ilmu Kesehatan Universitas Muhamadiyah Tangerang, yang kemudian menghasilkan data deskriptif berupa kata-kata tertulis atau lisan dari orang-orang dan perilaku yang diamati pada saat proses pengambilan data dilakukan, dengan tehnik wawancara, dokumentasi dan lembar ceklist data.

Penelitian ini dilakukan di Program Studi D-IV Bidan Pendidik Fakultas Ilmu Kesehatan Universitas Muhammadiyah Tangerang yang berlokasi di Jl. Perintis Kemerdekaan I, No. 33, Cikokol, Kota Tangerang, Banten, Indonesia, dengan rentang waktu penelitian selama 8 (delapan) bulan.

Tehnik dan prosedur pengumpulan data yang dilakukan dalam penelitian ini, peneliti bertindak sebagai instrumen yang melakukan pengumpulan data sekaligus mengolah data dan melaporkan hasil penelitian. Data primer diperoleh melalui observasi dan wawancara semi terstruktur dengan beberapa pertanyaan terbuka sebagai media interaksi yang dilakukan secara langsung kepada informan untuk menghasilkan data, serta didukung oleh beberapa perangkat seperti pedoman wawancara dan daftar ceklis. Data sekunder yang didapat dari silabus Mata Kuliah Metodologi Penelitian yang digunakan sebagai acuan pelaksanaan pembelajaran Metodologi Penelitian oleh Program Studi D-IV Bidan Pendidik Fakultas Ilmu Kesehatan Universitas Muhammadiyah Tangerang pada Tahun Akademik 2015/2016.

Objek yang diamati adalah seluruh mahasiswa Program Studi D-IV Bidan Pendidik Fakultas Ilmu Kesehatan Universitas Muhammadiyah Tangerang yang telah mendapat perkuliahan Metodologi Penelitian di Semester Ganjil Tahun Akademik 2015/2016. Kemudian melalui teknik Purposive Snowball Sampling, didapatkan 3 (tiga) orang mahasiswa sebagai informan.

Berikut kerangka fikir penelitian dalam objek penelitian ini :

Gambar. 1

Kerangka Pikir Penelitian

Objek Penelitian

Objek Penelitian

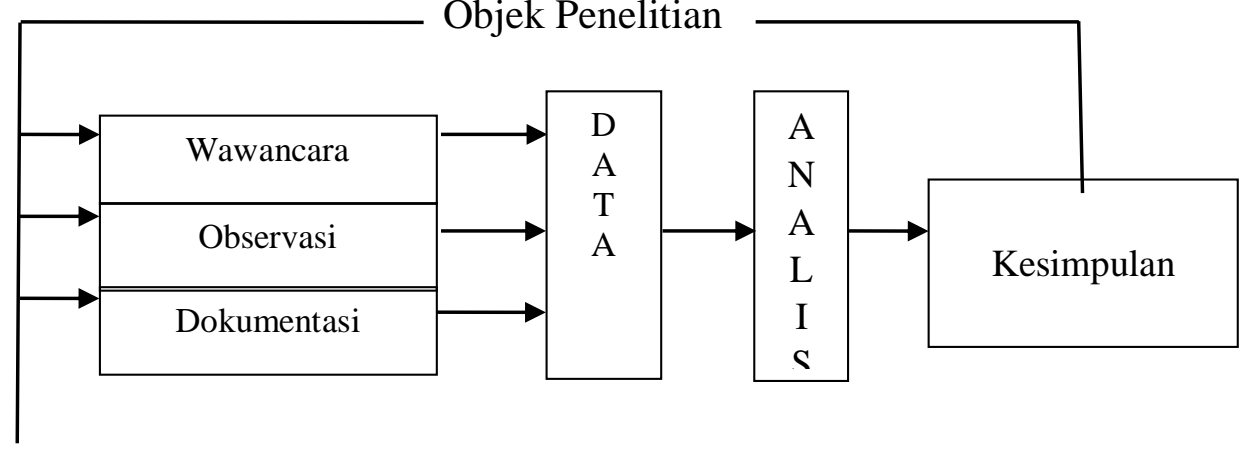


Standar Evaluasi yang digunakan pada penelitian ini adalah Silabus Mata Kuliah Metodologi Penelitian.

Dalam penelitian ini, peneliti melakukan pemeriksaan keabsahan data menggunakan teknik triangulasi metode, dimana peneliti melakukan pengecekan derajat kepercayaan penemuan hasil penelitian dengan cara membandingkan hasil wawancara dan daftar ceklis yang sama terhadap ketiga informan.

Adapun teknik analisis data yang digunakan dalam penelitian ini adalah Teori Miles dan Huberman, yakni model analisis interaktif yang digambarkan dengan skema berikut :

Gambar. 2

Teknik Analisis Data

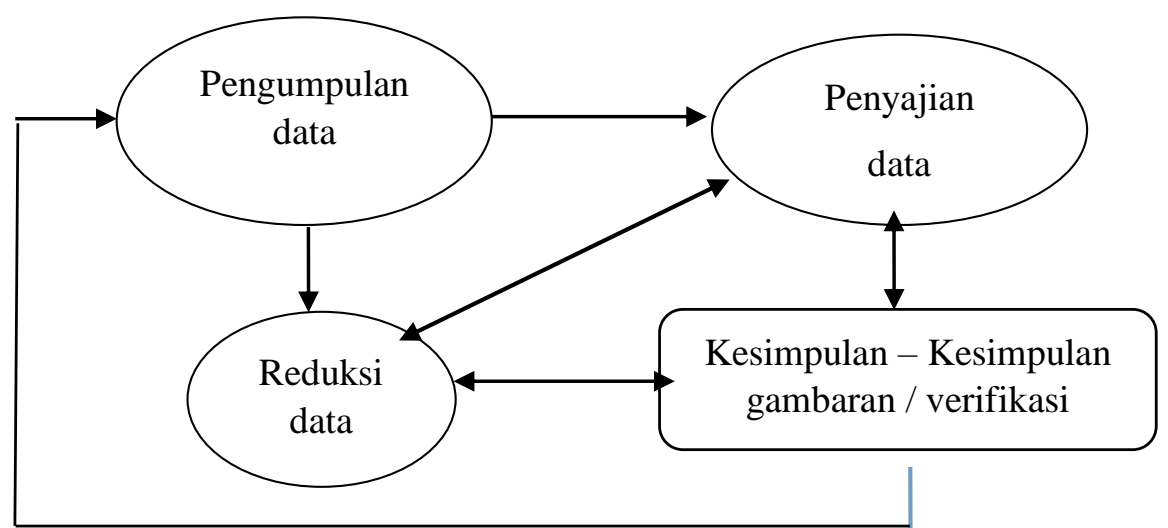

(Sugiyono, 2013)

Dari proses pengumpulan data melalui observasi dan wawancara, peneliti langsung melakukan analisis terhadap berbagai jawaban informan dan melakukan reduksi data dengan memilih dan memfokuskan pada hal-hal yang pokok, dan mencari polanya agar diperoleh sajian data yang lebih jelas sehingga memudahkan peneliti dalam memahami fenomena yang terjadi untuk kemudian menuangkannya dalam kesimpulan.

\section{PEMBAHASAN}

Pada Tahun Akademik 2015/2016, mahasiswa Program Studi D-IV Bidan Pendidik berjumlah 63 orang, yang terbagi dalam dua kelas yaitu kelas A1 dengan jadwal perkuliahan umum pada hari senin, selasa, sabtu dan kelas A2 pada hari kamis, jumat dan sabtu masing-masing dimulai pada pukul 13.00 - selesai.
Mata Kuliah Metodologi Penelitian Kebidanan dengan kode mata kuliah Bd.402 memiliki bobot 2 SKS (T1, P1), diberikan pada mahasiswa pada semester 1 (ganjil) yang dijadwalkan dalam silabus memiliki $14 \mathrm{x}$ pertemuan masing-masing selama 150 menit. (Silabus Mata Kuliah Metodologi Penelitian Kebidanan)

Dalam deskripsi singkat disebutkan bahwa mata kuliah ini merupakan mata kuliah yang terintegrasi dalam epidemiologi, biostatistik dan analisa data dengan sistem computer. Serta menggunakan competency based learning serta metoda interaktif yang membentuk mahasiswa terlibat aktif. (Silabus Mata Kuliah Metodologi Penelitian Kebidanan)

Strategi pembelajaran mata kuliah ini menggunakan metode ceramah, diskusi, seminar, praktikum studi kasus, role play dan praktik klinik. Metode ceramah digunakan di awal pembelajaran dosen 
menjelaskan dan menguraikan materi dan mahasiswa dapat mengajukan pertanyaan jika ada penjelasan yang kurang bisa dipahami. Metode diskusi digunakan pada saat mahasiswa yang telah dibagi kedalam beberapa kelompok mengerjakan penugasan sesuai dengan pokok bahasan yang diberikan oleh dosen. Metode seminar dilakukan saat mahasisswa menyampaikan hasil dari diskusi kelompok di depan kelas mereka masing masing menggunakan peralatan yang sesuai dan waktu yang ditentukan. Untuk metode praktikum dilakukan dengan cara studi kasus yang diberikan oleh dosen dan dibahas oleh mahasiswa sesuai petunjuk yang telah diajarkan. Mahasiswa diharapkan dapat menggunakan teknik berpikir kritis dalam memanfaatkan berbagai metode tersebut. (Silabus Mata Kuliah Metodologi Penelitian Kebidanan)

Kriteria penilaian pada Mata Kuliah Metodologi Penelitian Kebidanan menggunakan kriteria sebagai berikut ;

$\begin{array}{lccc}\text { Nilai } & & \text { poin } & \text { range } \\ \text { A } & 4 & & >/=80 \\ \text { B } & 3 & & 70-79 \\ \text { C } & 2 & & 60-69 \\ \text { D } & 1 & & 50-59 \\ \text { E } & 0 & & </=49 \\ \text { (Silabus } & \text { Mata } & \text { Kuliah } & \text { Metodologi }\end{array}$
Penelitian)

Evaluasi yang digunakan untuk mencapai sasaran pembelajaran Mata Kuliah Metodologi Penelitian Kebidanan adalah :

1. Ujian tulis tengah semester: $20 \%$

2. Ujian tulis akhir semester : $25 \%$

3. Tugas dan Seminar : $35 \%$

4. Kehadiran : $20 \%$

Total : $100 \%$

(Silabus Mata Kuliah Metodologi Penelitian Kebidanan)

Berdasarkan hasil observasi dan wawancara yang telah dilakukan terhadap 3 (tiga) orang mahasiswa Program Studi DIV Bidan Pendidik, diperoleh gambaran mengenai situasi pembelajaran Mata Kuliah Metodologi Penelitian di Program Studi D-IV Bidan Pendidik Fakultas Ilmu
Kesehatan Universitas Muhammadiyah Tangerang.

Metodologi Penelitian diampu oleh satu orang dosen. Dengan jeda istirahat sebanyak 2 (dua) kali pada jam 12.00 dan jam 16.00 selama 15 menit. Masing-masing pertemuan dimulai pukul 08.00 dan berakhir pada kisaran pukul $17.00 \mathrm{~s} / \mathrm{d}$ 18.00 .

Peneliti sependapat dengan teori yang dikemukakan oleh Dimyati (2011), "Dalam belajar diperlukan konsentrasi dalam perwujudan perhatian terpusat." Sementara penerapan sistem pembelajaran Metodologi Penelitian yang telah dipaparkan sebelumnya, menurut peneliti tentu memicu kejenuhan yang akan secara langsung berdampak pada hilangnya konsentrasi mahasiswa. Seperti yang diungkapkan informan mahasiswa 3;

"...waktunya kita kan dari pagi sampe sore jadi rada-rada jenuh kalau udah sore tuh jadi kelelahan. udah mah panjang ngejelimet."

Menurut pandangan peneliti, konsentrasi besar pengaruhnya terhadap belajar, mahasiswa yang tidak dapat berkonsentrasi jelas tidak akan berhasil menyimpan atau menguasai bahan pelajaran. Hal ini dibuktikan oleh penelitian yang dilakukan oleh Izzati (2014), Yang menyatakan bahwa Waktu perkuliahan dan lingkungan kelas berpengaruh signifikan terhadap konsentrasi belajar.

Pada kenyataannya, berdasarkan hasil wawancara dapat disimpulkan bahwa tingkat konsentrasi belajar mahasiswa Program Studi D-IV Bidan Pendidik Fakultas Ilmu Kesehatan Universitas Muhammadiyah Tangerang, masih rendah ketika mengikuti perkuliahan Metodologi Penelitian, hal ini terlihat pada lembar ceklis dimana seluruh informan menyatakan sangat setuju terhadap pernyataan yang berbunyi ; Pada saat proses pembelajaran Metodologi Penelitian di kelas pada Program Studi D-IV Bidan Pendidik, informan merasa lelah dan sulit menyerap materi dikarenakan durasi pertemuan waktu yang terlalu panjang 
dengan bobot materi yang berat sekaligus dalam satu hari.

Penerapan pembelajaran seperti ini juga kurang sesuai dengan prinsip belajar yang efektif menurut Ati (2014), dimana Menurut sistem kredit semester (SKS) mahasiswa belajar setidaknya dua jam di luar kelas untuk setiap jam belajar di kelas.

Pembelajaran Mata Kuliah Metodologi Penelitian untuk kelas A1 dan A2 dilakukan secara bersamaan dalam satu ruangan. Seperti yang diungkapkan oleh informan mahasiswa 1 ;

“..tidak fokus. Karena banyak orang dalam satu kelas.. jarak dosen ke mahasiswa paling belakang itu terlalu jauh... Modelnya (susunan tempat duduknya) memanjang dari depan ke belakang."

Peneliti sepaham dengan teori dari Winataputra (2003), yang mengungkapkan bahwa pembelajaran yang efektif dapat bermula dari iklim kelas yang dapat menciptakan suasana belajar yang menggairahkan, untuk itu perlu diperhatikan pengaturan/ penataan ruang kelas dan isinya, selama proses pembelajaran. Lingkungan kelas perlu ditata dengan baik sehingga memungkinkan terjadinya interaksi yang aktif antara pengajar dengan mahasiswa.

Menurut peneliti, penataan lingkungan fisik kelas sangat perlu diperhatikan oleh pengajar. Hal ini dibuktikan pada uji coba yang dilakukan oleh Efendi (2015) yang menyatakan bahwa jumlah siswa per kelas berpengaruh signifikan terhadap hasil belajar, efektifnya tiap rombongan belajar berisi antara 17-20 orang.

Perkuliahan Metodologi Penelitian pada Program Studi D-IV Bidan Pendidik Fakultas Ilmu Kesehatan Universitas Muhammadiyah Tangerang seharusnya dilaksanakan dalam beberapa kali pertemuan atau tatap muka, namun dilakukan dalam satu kali pertemuan saja sekaligus. Atau kerap disebut dengan istilah perkuliahan blok. Seperti yang diungkapkan oleh informan 3; “...pembelajaran mata kuliahnya (teorinya), sampe latihannya sampe masuk ke $B A B$ berikutnya lagi itu dalam satu waktu gitu yang ada bikin mahasiswanya bosen."

Peneliti berpendapat hal ini kurang efektif, dikarenakan semakin panjangnya waktu perkuliahan dalam satu kali tatap muka mengakibatkan hilangnya fokus dan perhatian mahasiswa akibat rasa jenuh dan lelah yang kemudian berbanding lurus dengan menurunnya minat mahasiswa terhadap perkuliahan tersebut. Sedangkan menurut teori yang dikemukakan oleh Prayitno (2009), Seorang mahasiswa harus mempunyai perhatian terhadap bahan yang dipelajarinya.

Hal ini sejalan juga dengan teori Cronbach (2006), yang mengemukakan bahwa situasi belajar sangat mempengaruhi proses belajar, berupa tempat, lingkungan sekitar, alat dan bahan yang dipelajari.

Perkuliahan dilakukan pada hari minggu dengan jumlah tatap muka sebanyak 2 (dua) kali. Hal ini tidak sesuai dengan jadwal perkuliahan yang semestinya yaitu pada hari senin, selasa dan sabtu atau kamis, jumat dan sabtu. seperti yang diungkapkan oleh informan;

"Kita kuliah kan seharusnya senin selasa sabtu untuk A1, dan rabu kamis sabtu untuk A2.. kita kuliah di satuin gitu di hari minggu. Dua kali.." (mahasiswa 2)

"Terus jadwal kuliahnya juga menclak menclok, kayaknya kalo ada kosong langsung di isi metlit, nggak kontinyu jadinya. Naro jadwalnya kayak ya menclak menclok gitu. Jadi kan ngacak pikiran nya juga"'(mahasiswa 3)

Hal ini tentu berpengaruh pada kesiapan belajar mahasiswa dan beban yang diterima, seperti teori Cronbach (2006), yang mengemukakan bahwa beberapa unsur utama dalam proses belajar adalah Kesiapan Belajar. Dimana pembelajaran dapat berjalan apabila peserta memiliki kesiapan, baik kesiapan fisik dan psikis, kesiapan yang berupa kematangan untuk melakukan sesuatu, maupun penguasaan pengetahuan dan kecakapan-kecakapan. 
Dalam mengerjakan UTS dan UAS tulis mahasiswa merasa tidak ada kesulitan, dikarenakan sebelum ujian mahasiswa telah terlebih dahulu menerima kisi-kisi soal dari dosen. Namun pada saat pengerjaan proposal penelitian, mahasiswa mengeluh merasa kesulitan dalam mengerjakannya. Seperti yang dikemukakan oleh informan mahasiswa 3 pada saat wawancara,

“...karena dikasih kisi-kisi jadi ya gampang-gampang aja UTS/UAS sih. Kisikisinya juga sama persis. Cuman pas ngerjain skripsi itu pasti butuh bantuan lagi..."

Serta pada daftar ceklis didapatkan seluruh informan menyatakan sangat setuju pada pernyataan "Pada saat UTS dan UAS terdapat kisi-kisi yang jelas sehingga sangat memudahkan dalam pengerjaan soal", Dan "pada saat proses pengerjaan skripsi mahasiswa membutuhkan bantuan tambahan (misal dari teman, atau pihak lain yang ahli dalam metodologi penelitian) karena masih merasa kesulitan dalam mengaplikasikan Metodologi Penelitian secara nyata dalam penelitian."

Metode pembelajaran Metodologi Penelitian yang diterapkan Pada Program Studi D-IV Bidan Pendidik Fakultas Ilmu Kesehatan Universitas Muhammadiyah Tangerang adalah metode ceramah dan latihan soal singkat. Menurut peneliti, perpaduan kedua metode ini telah sesuai dan tidak menimbulkan masalah yang signifikan. Hal ini sesuai dengan pernyataan informan;

"enak lho dosenya itu sebenernya" (mahasiswa 2)

"dosen mata kuliah metlit itu cara mengajarnya cukup bagus" (mahasiswa 1)

Dari berbagai uraian di atas terlihat adanya ketidaknyamanan dari mahasiswa dalam mengikuti pembelajaran yang merujuk pada ketidak sesuaian antara standar kemampuan mahasiswa dengan pembelajaran yang diterapkan.

Peneliti dapat menyimpulkan bahwasanya terdapat ketidak sesuaian pada standar kemampuan mahasiswa terhadap pembelajaran Mata Kuliah Metodologi Penelitian pada Program Studi D-IV Bidan Pendidik Fakultas Ilmu Kesehatan Universitas Muhammadiyah Tangerang Tahun Akademik 2015/2016 dengan standar evaluasi yang telah ditetapkan. Beberapa perbaikan dalam sistem pembelajaran Metodologi Penelitian sangat perlu untuk dilakukan.

\section{KESIMPULAN DAN REKOMENDASI}

Beradasarkan hasil temuan penelitian, peneliti mengambil kesimpulan, bahwasanya terdapat ketidak sesuaian pada standar kemampuan mahasiswa terhadap pembelajaran Mata Kuliah Metodologi Penelitian di Program Studi D-IV Bidan Pendidik Fakultas Ilmu Kesehatan Universitas Muhammadiyah Tangerang Tahun Akademik 2015/2016 dengan standar evaluasi yang telah ditetapkan. Beberapa perbaikan dalam sistem pembelajaran Metodologi Penelitian sangat perlu untuk dilakukan.

Rekomendasi dari hasil penelitian ini adalah;

A. Bagi Program Studi D-IV Bidan Pendidik Fakultas Ilmu Kesehatan Universitas Muhammadiyah Tangerang

- Melakukan mapping jadwal perkuliahan yang dibentuk secara baku dan pasti, kemudian disosialisasikan dan diinformasikan kepada mahasiswa sejak awal, tidak mendadak.

- Melakukan koordinasi sebaik mungkin dengan dosen, untuk menghindari ketidak stabilan jadwal perkuliahan.

- Perkuliahan Metodologi Penelitian di Program Studi D-IV Bidan Pendidik Fakultas Ilmu Kesehatan Universitas Muhammadiyah Tangerang dilakukan secara terpisah antara kelas A1 dengan A2.

B. Bagi Dosen Metodologi Penelitian Program Studi D-IV Bidan Pendidik Fakultas Ilmu Kesehatan Universitas Muhammadiyah Tangerang 
- Mempertahankan metode yang telah digunakan dan menambah beberapa variasi untuk mengurangi kejenuhan

- Melakukan manajemen tata letak kelas sehingga tidak ada mahasiswa yang merasa terlalu jauh dari dosen sehingga tidak dapat mengikuti perkuliahan yang sedang berlangsung

- Menambah porsi latihan pengerjaan soal dan memperdalam praktikum

C. Bagi Mahasiswa Program Studi D-IV Bidan Pendidik Fakultas Ilmu Kesehatan Universitas Muhammadiyah Tangerang

- Lebih tertib dalam menjalani perkuliahan, sehingga proses perkuliahan bisa berjalan dengan baik, dan seluruh mahasiswa dapat fokus mengikuti perkuliahan yang disampaikan.

- Menambah referensi dari luar kelas untuk melatih kemampuan Metodologi Penelitian

- Lebih aktif secara mandiri mempelajari ulang berbagai materi yang telah diberikan dikelas dan berdiskusi dengan teman.

\section{DAFTAR PUSTAKA}

Arif, Rahman. 2013. Memahami Ilmu Pendidikan, Yogyakarta: CV. Aswaja Pressindo.

Arifin, Zainal. 2011. Evaluasi Pembelajaran. Prinsip, Teknik Dan Prosedur.

Arifin, Zainal. 2011. Konsep dan Model Pengembangan Kurikulum. Bandung : Remaja Rosdakarya.

Arikunto, S. (2007). Dasar-dasar Evaluasi Pendidikan. Jakarta: PT Bumi Aksara.

Bandung: Remaja Rosdakarya.

Bungin, B. 2007. Penelitian Kualitatif. Prenada Media Group: Jakarta.

CIPP Model of Evaluation. (n.d.). Retrieved September 10, 2014, from Wikipedia The Free Encyclopedia: http://en.wikipedia.org

Dimyati Mahmud, M. (2011). Psikologi Pendidikan. Jakarta : Dept P dan K. Dirjen Perguruan Tinggi.
Endang Soenaryo, Pengantar Teori Perencanaan Pendidikan Berdasarkan Pendidikan Sistem, Adicita Karya Nusa, Yogyakarta, 2000.

Izzati, Rosyida Rahma. 2014. Pengaruh Waktu Perkuliahan Dan Lingkungan Kelas Terhadap Tingkat Konsentrasi Belajar Akuntansi Biaya 2 Pada Mahasiswa Pendidikan Akuntansi Angkatan 2011 Universitas Muhammadiyah Surakarta. Surakarta: Universitas Muhammadiyah Surakarta.

Komsiyah, Indah. 2012. Belajar Dan Pembelajaran. Yogyakarta: Teras.

Mirza Bashirudin Ahmad, dkk. 2013. Model Evaluasi Kurikulum Goal Free Evaluation Model. Universitas Negeri Yogyakarta.

Moleong, Lexy j. 2014. Metode Penelitian Kualitatif. Edisi revisi. Cetakan ke tiga puluh dua. Bandung. PT Remaja Rosdakarya

Muhibbin,Syah. 2013. Psikologi Pendidikan dengan Pendekatan Baru. Bandung: Remaja Rosda Karya.

Ngalim Purwanto, M. 2012. PrinsipPrinsip dan Teknik Evaluasi Pengajaran. Bandung: Remaja Rodakarya.

Prayitno, Elida. 2009. Motivasi Dalam Belajar. Jakarta: Dept P dan K. Dirjen Perguruan Tinggi.

Riyana, Cepi. 2012. Modul 6 Kurikulum Pembelajaran: Komponen-Komponen Pembelajaran. Bandung: Universitas Pendidikan Indonesia.

Santoso, N. 2015. Evaluasi Sistem Pembelajaran. Jakarta. Diakses dari http://santoson111.blogspot.co.id/20 15/09/makalah-evaluasi-sistem pembelajaran.html

Sudaryono. 2012. Dasar-Dasar Evaluasi Pembelajaran. Yogyakarta: Graha Ilmu.

Sudjana, N., \& Ibrahim. (2009). Penelitian dan Penilaian Pendidikan. Bandung: Sinar baru Algensindo.

Sugiyono. 2013. Memahami Penelitian Kualitatif. Bandung: Alfabeta. 
Tayibnapis, Farida. 2008. Evaluasi Program dan Instrument Evaluasi untuk Program Pendidikan dan Penelitian. Jakarta: PT Rineka Cipta

Trianto. 2010. Mendisain Model Pembelajaran Inovatif-Progresif. Jakarta: Kharisma Putu Utama.

Winataputra, Udin S. 2003. Srategi Belajar Mengajar. Jakarta: Universitas Terbuka Departemen Pendidikan Nasional

Yunanda. 2009. Evaluasi Hasil Dan Proses Pembelajaran. Yogyakarta: Universitas Gajah Mada. Diunduh dari https://www.scribd.com

/document/86615082/Tugas-1-

Evaluasi-Hasil-Dan-Proses-

Pembelajaran

http://penalaranunm.org/artikel/penelitian/132metode-penelitian-kualitatif.html

http://sulfiana22.blogspot.co.id/2014/12/ pengertian-sistem-dalampembelajaran.html 2/16/16 